\title{
Bacterial response to hydrostatic pressure in seawater samples collected in mixed-water and stratified-water conditions
}

\author{
Armand Bianchi, Jean Garcin \\ Microbiologie Marine, CNRS UPR 223, Campus de Luminy case 907, F-13288 Marseille Cedex 9, France
}

\begin{abstract}
Effects of hydrostatic pressure conditions on microbial incorporation of ${ }^{14} \mathrm{C}$-glucose were studied in $3 \mathrm{~h}$ incubations of decompressed and undecompressed seawater samples collected at $1100 \mathrm{~m}$ depth in the northwestern Mediterranean Sea. Even in these relatively shallow environments, hydrostatic pressure conditions influence microbial activity measurement. Depending on hydrological conditions this parameter provokes stimulatory or adverse effects on microbial metabolism. During the stratified-water period, microbial activity in samples from $1100 \mathrm{~m}$ depth was reduced under decompressed conditions. On the other hand, during the mixed-water period microbial activity was stimulated by decompression. Therefore measurements of microbial activity in the water column must be done taking in situ pressure conditions into account.
\end{abstract}

KEY WORDS: Deep-sea bacteria $\cdot$ Bacterial activity Pressure-retaining sampler $\cdot$ Pressure effect

\section{INTRODUCTION}

Referring to the global oceanic system, most of the photosynthetic primary production is recycled into the upper layers of the water column. Nevertheless, the geochemical cycling in the global ocean cannot tolerate an irreversible loss of this organic material flowing or sinking to the sea bottom. Decomposition of this material depends mostly on the microbial activity in the deep-sea.

The most characteristic features of the deep-sea are scarcity of nutrients, low temperature and high pressure. To act efficiently in deep environments, bacteria have to be adapted to these conditions. Particularly, indigenous deep-sea bacteria should be well-adapted to high-pressure conditions. On the other hand, allochthonous bacteria, coming from the upper part of the water column, would appear unadapted to highpressure conditions (Yayanos et al. 1982). Depending on the hydrological conditions, the proportion of allochthonous and indigenous bacteria in deep-sea microflora can vary. This discrepancy could explain the contradictory results concerning the effects of hydrostatic pressure on the microbial activity of sea- water samples collected in diverse areas (Jannasch \& Wirsen 1973, Wada et al. 1975, Jannasch et al. 1976 , Deming 1985, Deming \& Colwell 1985, Cahet \& Sibuet 1986, Cowen 1989, De Angelis et al. 1991).

Sampling northwestern Mediterranean waters at $1100 \mathrm{~m}$ depth in stratified conditions we have previously observed a reduction of microbial activity by decompression during retrieval (Bianchi \& Garcin 1993). Here we present the comparison of microbial activity exerted in decompressed and undecompressed samples collected at the same depth, but in stratifiedand mixed-water conditions.

\section{MATERIAL AND METHODS}

Study sites. We collected surface-water samples (20 $\mathrm{m}$ deep) and deep-water samples $(1100 \mathrm{~m})$ in 2 areas in the northwestern Mediterranean Sea where the sea bottom is $1700 \mathrm{~m}$ deep (Fig. 1). The first area, 30 miles southeast of Marseilles, was sampled in stratified-water conditions. The second area, 30 miles southeast of Nice, was sampled both during a mixedwater period and in stratified-water conditions. In this 


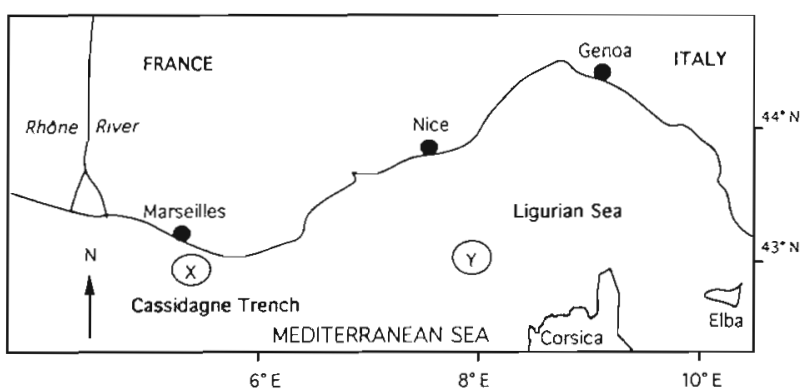

Fig. 1. Location of the sampling stations in the northwestern Mediterranean Sea. Stn $X$ is in the Cassidagne Trench area (stratified waters), Stn $\mathrm{Y}$ is in the Ligurian Sea (mixed or stratified waters depending on sampling period)

part of the Mediterranean Sea, at $20 \mathrm{~m}$ depth, seawater temperature is ca $20^{\circ} \mathrm{C}$ in summer, and $13^{\circ} \mathrm{C}$ in winter. The $1100 \mathrm{~m}$ deep water is always ca $13^{\circ} \mathrm{C}$.

Sampling procedure. Surface water samples were collected from a depth of $20 \mathrm{~m}$ using a Niskin sampler. Before use, the Niskin sampler was acid-cleaned $(10 \%$ $\mathrm{HCl}$ in distilled water), alcohol-sterilized (50/50: v/v) and rinsed with sterile distilled water. Deep-sea samples were collected at $1100 \mathrm{~m}$ depth with a pressureretaining sampler (PRS) already described (Bianchi \& Garcin 1993) and with a Niskin sampler fixed $1 \mathrm{~m}$ above the PRS, on the same hydrowire. The Niskin samples were transferred immediately into sterile polycarbonate vessels. These vessels and the PRS were transported to the land-laboratory in polystyreneinsulated containers. Under these conditions temperature change during transportation was limited to $\pm 2^{\circ} \mathrm{C}$. This transport delayed sample processing by less than $4 \mathrm{~h}$.

Microbial activity measurements. Decompressed samples were incubated in 21 polycarbonate flasks kept in the dark under ambient atmosphere at in situ temperature $\pm 0.5^{\circ} \mathrm{C}$. A fraction of the decompressed samples was transferred into six $150 \mathrm{ml}$ stainless steel cultivating devices pre-chilled in a water bath at in situ temperature and then compressed to $11.14 \mathrm{MPa}$ of hydrostatic pressure. We previously ensured that microbial activity measurements resulting from a $3 \mathrm{~h}$ incubation period in polycarbonate vessels or in these stainless steel vessels did not differ significantly (Bianchi \& Garcin 1993).

Undecompressed samples were distributed without decompression into six $150 \mathrm{ml}$ cultivating devices (Bianchi \& Garcin 1993) pre-chilled in a water bath at in situ temperature. We used D-(U- $\left.{ }^{14} \mathrm{C}\right)$-glucose, specific activity $10.6 \mathrm{GBq} \mathrm{mmol}^{-1}$ (Amersham Corp.), as radiolabeled substrate. For both decompressed and undecompressed samples the final concentration was $5.8 \mathrm{nmol}$ glucose $1^{-1}$.
After labeling, $150 \mathrm{ml}$ subsamples were formalin fixed (final concentration $1 \%$ ), at zero-time (control), $30,60,90,120$ and $180 \mathrm{~min}$. Fixed samples were filtered through $0.2 \mu \mathrm{m}$ polycarbonate filters. Radioactivity was counted by liquid scintillation (Beckman LS 1800). Counting efficiency and quenching correction were determined by use of internal standards. Data were corrected against those from control samples fixed immediately after label addition.

Preliminary studies showed that in these deep Mediterranean waters a $5 \mathrm{nM}$ glucose concentration was above the saturation concentration of the glucose uptake systems. Therefore we estimated the maximal carbon incorporation rate $\left(V m, \mathrm{~g} \mathrm{Cl}^{-1} \mathrm{~h}^{-1}\right)$ according to:

$V m=\frac{\mathrm{dpm} \text { incorporated } \times \mathrm{g} \mathrm{C} \mathrm{dpm}^{-1} \times 1000}{\text { Incubated volume }(\mathrm{ml}) \times \text { Incubation time }(\mathrm{h})}$

Glucose assimilation rates were not normalized to bacterial numbers, as epifluorescence microscopy does not allow the determination of the actual percentage of bacteria able to use ${ }^{14} \mathrm{C}$-glucose.

Bacterial numbers. Samples for bacterial counts were fixed in $2 \%$ formalin, stored at $4{ }^{\circ} \mathrm{C}$ and stained with diamidinophenylindole (Porter \& Feig 1980). Filters were enumerated by epifluorescence microscopy (Olympus, BH2).

\section{RESULTS}

\section{Bacterial activity in surface waters}

Bacterial densities range between 3.6 and $7.6 \times 10^{5}$ cells $\mathrm{ml}^{-1}$ in the surface-water and between 0.9 and $9.3 \times$ $10^{4}$ cells $\mathrm{ml}^{-1}$ in deep-water samples collected in the Cassidagne Trench and in the Ligurian Sea (Table 1).

Samples collected at $20 \mathrm{~m}$ depth in the Cassidagne Trench area during fall appeared moderately active in ${ }^{14} \mathrm{C}$-glucose incorporation, with a mean of $251 \pm$ $35.1 \mathrm{pg} \mathrm{Cl}^{-1} \mathrm{~h}^{-1}( \pm \mathrm{SE}, \mathrm{n}=10$ ) (Table 1). Samples collected at the same depth in the Ligurian Sea during winter appeared less active than those collected under fall conditions (at equal temperature conditions) in the Cassidagne Trench, with a mean value of $174.3 \pm$ $24.2 \mathrm{pg} \mathrm{Cl}^{-1} \mathrm{~h}^{-1}(\mathrm{n}=6)$. Samples collected in the same area in summer $\left(\mathrm{T}=20^{\circ} \mathrm{C}\right)$ appeared more active in ${ }^{14} \mathrm{C}$-glucose incorporation $\left(706.6 \pm 73.4 \mathrm{pg} \mathrm{C} \mathrm{l}^{-1} \mathrm{~h}^{-1}\right.$, $\mathrm{n}=4$ ).

\section{Simulation of surface water sinking}

Table 1 shows that when winter surface-water samples were pressurized at $11.14 \mathrm{MPa}$, simulating a sinking of water to $1100 \mathrm{~m}$ depth, carbon incorporation into 


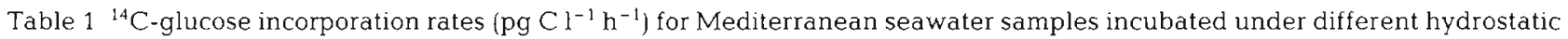
pressure conditions. Mean values \pm SE. Number of samples given in parentheses. Temp.. in situ temperature is also incubation temperature; Bacteria: total number (epifluorescence microscopy); Atm. pressure: samples decompressed during retrieval and incubated under atmospheric pressure conditions; nd: not determined

\begin{tabular}{|c|c|c|c|c|c|c|}
\hline \multirow{2}{*}{ Sampling area } & \multirow{2}{*}{$\begin{array}{l}\text { Hydrological } \\
\text { conditions }\end{array}$} & \multirow{2}{*}{$\begin{array}{l}\text { Sampling } \\
\text { depth (m) }\end{array}$} & \multirow{2}{*}{$\begin{array}{l}\text { Temp. } \\
\left({ }^{\circ} \mathrm{C}\right)\end{array}$} & \multirow{2}{*}{$\begin{array}{c}\text { Bacteria } \\
\left(10^{4} \mathrm{ml}^{-1}\right)\end{array}$} & \multicolumn{2}{|c|}{ Glucose uptake rates } \\
\hline & & & & & Atm. pressure & $11.4 \mathrm{MPa}$ \\
\hline Cassidagne Trench & Stratified & 20 & 13 & $54.0 \pm 4.5$ & $251.0 \pm 35(10)$ & $22.1 \pm 7(3)^{a}$ \\
\hline Ligurian Sea & Mixed & 20 & 13 & $35.8 \pm 3.8$ & $174.3 \pm 24(6)$ & $30.5 \pm 4(3)^{\alpha}$ \\
\hline Ligurian Sea & Stratified & 20 & 20 & $57.6 \pm 4.3$ & $706.6 \pm 73(4)$ & nd \\
\hline Cassidagne Trench & Stratified & 1100 & 13 & $2.2 \pm 0.4$ & $30.7 \pm 10(6)$ & $78.5 \pm 24(6)^{t}$ \\
\hline Ligurian Sea & Stratified & 1100 & 13 & $3.4 \pm 0.6$ & $23.6 \pm 14(8)$ & $59.5 \pm 11(8)^{t}$ \\
\hline Ligurian Sea & Mixed & 1100 & 13 & $7.3 \pm 2.1$ & $421.2 \pm 43(3)$ & $14.5 \pm 6(3)^{b}$ \\
\hline
\end{tabular}

the microbial biomass at $13^{\circ} \mathrm{C}$ decreased drastically $\left(22.1 \pm 7.3\right.$ and $30.5 \pm 4.4 \mathrm{pg} \mathrm{C}^{-1} \mathrm{~h}^{-1}$ for Cassidagne Trench and Ligurian Sea samples, respectively).

\section{Bacterial activity in deep samples}

Bacteria collected at $1100 \mathrm{~m}$ depth in the Cassidagne Trench, under stratified-water conditions at $13^{\circ} \mathrm{C}$, were less active than surface-water bacteria. Carbon incorporation rates (Table 1) appeared significantly higher in the undecompressed samples $(78.5 \pm 24.4 \mathrm{pg}$ $\left.\mathrm{C}^{-1} \mathrm{~h}^{-1}, \mathrm{n}=6\right)$, than in the decompressed ones $(30.7 \pm 10.2 \mathrm{SE}, \mathrm{n}=6)$. Difference appeared significant at $\mathrm{p}<0.05$.

Four samples in both winter and summer were collected in the Ligurian Sea at $1100 \mathrm{~m}$ depth in stratifiedwater conditions. For all these samples, incorporation rates were lower than those exerted by the Cassidagne Trench samples (Table 1). The 'dpm incorporated' of some samples were not higher than formalin killed blanks, as already observed in this area by Cahet \& Jacques (1976). When active, these microflora exhibited a barophilic behavior, as did the Cassidagne Trench deep-sea microflora, being significantly (at $p<0.05$ ) more active when incubated without decompression $\left(59.5 \pm 10.9 \mathrm{pg} \mathrm{Cl}^{-1} \mathrm{~h}^{-1}, \mathrm{n}=8\right)$ than under atmospheric pressure $\left(23.6 \pm 14.4 \mathrm{pg} \mathrm{Cl}^{-1} \mathrm{~h}^{-1}, \mathrm{n}=8\right)$.

Bacteria collected at the same sampling station at the same depth in the Ligurian Sea during the mixed-water period responded to pressure in the opposite way that microorganisms sampled in stratified-water conditions did. In these samples, we observed an adverse pressure effect on carbon assimilation (Table 1). Bacteria decompressed during retrieval and incubated at atmospheric pressure appeared significantly more active $(421.2 \pm$ $43.3 \mathrm{pg} \mathrm{Cl}^{-1} \mathrm{~h}^{-1}$ at $\left.\mathrm{p}<0.005\right)$ than the undecompressed ones (14.5 $\left.\pm 6.3 \mathrm{pg} \mathrm{Cl}^{-1} \mathrm{~h}^{-1}, \mathrm{n}=3\right)$.
Generally, bacterial densities did not vary significantly in the samples during the $3 \mathrm{~h}$ incubation period, regardless of the pressure conditions.

\section{DISCUSSION}

Microbial densities in seawater samples collected at $1100 \mathrm{~m}$ depth varied with the geographical sampling area and with time. Even under deep-sea conditions, bacteria are not homogeneously distributed in both space and time.

Microbial activity measurements showed a large discrepancy between surface-water and deep-water samples. Surface-water bacteria are not adapted to growth at high pressure, as observed by Turley (1993). In our study, activity in deep-water samples depended on hydrological conditions. Rheinheimer et al. (1989) reported differences of nearly 2 orders of magnitude between mixed layer and 'winter water' in the Baltic Sea. Poremba (1994) observed recently that microbial degradation of phytodetritus in deep-sea sediments was positively influenced by elevated pressure mostly in summer

Measurements of glucose assimilation without decompression or under atmospheric pressure conditions showed that hydrostatic pressure influences microbial activity. Pressure effects varied with the origin and the history of the microbial communities. Activity of surface-borne bacteria appeared to be affected by increased hydrostatic pressure. This adverse effect was observed on samples collected in the surface layers of the ocean (20 m depth), as well as on samples collected deeper in the water column $(1100 \mathrm{~m})$, when the seawater bodies rapidly sank to this depth. These bacteria exhibited lower metabolic activity when pressurized at the sampling depth pressure (11.14 MPa) than when under atmospheric pressure conditions. Our data are 
limited to the carbon assimilation rates, therefore we do not know the influence of increasing depth on microbial respiration rates. It is likely, however, that as any other stress (Tison \& Pope 1980, Griffiths et al. 1984), hydrostatic pressure also influences the respiratory rates.

These results contradict the previous observations by Wada et al. (1975) that nitrate metabolism in surface water is not substantially inactivated by exposure to high pressure (up to $600 \mathrm{~atm}$ ). But these authors used peptone and yeast extract enrichment (5.0 and $1.0 \mathrm{~g} \mathrm{l}^{-1}$, respectively) and incubation periods of 128 or $212 \mathrm{~h}$. These experimental conditions could have caused drastic modifications of the natural microbial community.

During the mixed-water period, bacterial concentration and activity at $1100 \mathrm{~m}$ depth were higher than usually found in this area at this depth. The samples decompressed during retrieval appeared 30 -fold more active than the undecompressed ones. This pattern of bacterial activity lets us suggest that bacteria sampled during mixed-water column conditions are surfacewater bacteria mixed into the deeper waters by hydrological processes. When incubated under atmospheric pressure, carbon assimilation by these samples appeared significantly higher than under stratified conditions in the Cassidagne Trench. More surprisingly, these bacteria collected at $1100 \mathrm{~m}$ appeared more active than the corresponding surface bacteria. We could hypothetize that some of the surface-borne microorganisms could be irreversibly damaged by the successive pressure stresses, releasing organic compounds into the incubation vessel. This enrichment could stimulate the metabolic activity of the surviving surface bacteria when relieved from the inhibitory effect of hydrostatic pressure.

Bacteria collected in deep-water masses in stratifiedwater conditions exhibited higher assimilation rates when incubated without decompression than at atmospheric pressure. The ratio undecompressed/decompressed is similar $(\approx 2.5)$ for the 2 sets of samples collected at the same depth in the Cassidagne Trench and in the Ligurian Sea. This ratio indicates that in stratified conditions the deep-sea bacteria are well adapted to the hydrostatic pressure conditions exerted in their natural environment.

In these experiments we were able to compare the microbial activity of surface-water and deep-sea samples using the same incubation temperature. In the Mediterranean Sea, during the late fall and winter period, temperature conditions $\left(13^{\circ} \mathrm{C}\right)$ vary only slightly or not at all over the whole water column. In this way, the Mediterranean offers an exceptional opportunity to compare the microbial activity throughout the water column under increasing pressure but constant tem- perature conditions. These conditions permit one to distinguish between the low-temperature and the high-pressure effects that are usually linked in cold deep-sea environments (ZoBell \& Johnson 1949, Jannasch \& Wirsen 1973, Wada et al. 1975, Yayanos \& Dietz 1982).

Decreasing the natural hydrostatic pressure conditions during sample retrieval and incubation can provoke either inhibitory or stimulatory effects on microbial cells. Our results demonstrate that these 2 opposite patterns could depend on the origin of the bacterial communities. In the marine environment, large scale transportations of free-living bacteria are mainly linked to hydrological conditions. Therefore the pressure effect, like temperature effects on natural communities (Bianchi 1987, Bird \& Karl 1991), depends on the history of seawater masses. The knowledge of hydrological conditions could explain some controversiai results in deep-sea microbial ecology.

\section{CONCLUSIONS}

Until now, most of the barophilic activities already described in the literature correspond to bacteria linked to the large particles sinking through the water column (Deming \& Colwell 1985), to bacteria associated with the digestive tracts of deep-sea invertebrates (Schwarz et al. 1976, Yayanos et al. 1979, Deming et al. 1981), or to microorganisms acting at the water-sediment boundary layer (Cahet \& Sibuet 1986). Free-living bacteria and bacteria attached to sinking particles react differently to increased hydrostatic pressure (Turley 1993). The 2 sampling devices used here, the Niskin sampler and the pressure-retaining sampler, do not collect the large sinking particles and, therefore, bacteria attached to large sinking particles would have been excluded. Our experiments showed clearly that the free-living bacteria and bacteria linked to small particles, comprising over $90 \%$ of the heterotrophic activity in marine waters (Azam \& Hodson 1977), are sensitive to pressure conditions.

These experiments demonstrated that, regardless of the hydrological conditions, microbial activity measurements on decompressed samples do not reflect the actual activity of the microbial consortia in the deep ocean. Depending on the mixing conditions, 'conventional' decompressed samples will yield either an under- or an overestimation of the actual microbial activity. It is difficult to assess a precise depth limit where pressure affects bacterial activity. Nevertheless our experiments showed that, in the Mediterranean environment, microbial activity was clearly affected by pressure conditions at $1100 \mathrm{~m}$ depth. 
Acknowledgements. The authors thank the 'Société Nationale Elf Aquitaine' for providing the pressure-retaining device (Convention SNEA \#8280). We are grateful to the captains and crews of RV 'Antedon' and RV 'Korotneff' for cruise assistance. Special thanks to Gerhard Herndl and to 3 reviewers for their helpful comments and suggestions to improve this manuscript. This work was supported by the Institut National des Sciences de l'Univers, Programmes Flux Océaniques EUMELI and DYFAMED.

\section{LITERATURE CITED}

Azam, F., Hodson, R. E. (1977). Size distribution and activity of marine microheterotrophs. Limnol. Oceanogr. 22: 492-501

Bianchi, A. (1987). Les effets de la température sur la microflore hétérotrophe des eaux de deux sites d'hydrothermalisme actif du Pacifique-Est $\left(13^{\circ} \mathrm{N}\right)$. Oceanol. Acta (Spec. Vol.) 8: 45-50

Bianchi, A., Garcin, J. (1993). In stratified waters the metabolic rate of deep-sea bacteria decreases with decompression. Deep Sea Res. 40: 1703-1710

Bird, D. F., Karl, D. M. (1991). Spatial patterns of glutamate and thymidine assimilation in Bransfield Strait, Antarctica during and following the austral spring bloom. Deep Sea Res. 38: 1057-1075

Cahet, G., Jacques, G. (1976). Assimilation du glucose dans la zone de divergence de Méditerranée Nord-occidentale. Int. Revue ges. Hydrobiol. 61: 649-685

Cahet, G., Sibuet, M. (1986). Activité biologique en domaine profond: transformations biochimiques in situ de composés organiques marqués au carbone-14 à l'interface eau-sédiment par $2000 \mathrm{~m}$ de profondeur dans le golfe de Gascogne. Mar. Biol. 90: 307-315

Cowen, J. P. (1989). Positive pressure effect on manganese binding by bacteria in deep-sea hydrothermal plumes. Appl. environ. Microbiol. 55: 764-766

De Angelis, M. A., Baross, J. A., Lilley, M. D. (1991). Enhanced microbial methane oxidation in water from a deep-sea hydrothermal vent at simulated in situ hydrostatic pressures. Limnol. Oceanogr. 36: 565-570

Deming, J. W. (1985). Bacterial growth in deep-sea sediment trap and box core samples. Mar. Ecol. Prog. Ser. 25: $305-312$

Deming, J. W., Colwell, R. R. (1985). Observation of barophilic microbial activity in samples of sediment and intercepted particulates from the Demerara abyssal plain. Appl. enviIon. Microbiol. 50: 1002-1006

This article was submitted to the editor
Deming, J. W., Tabor, P. S., Colwell, R. R. (1981). Barophilic growth of bacteria from intestinal tracts of deep-sea invertebrates. Microb. Ecol. 7: 85-94

Griffiths, R. P., Caldwell, B. A., Morita, R. Y (1984). Observations on microbial percent respiration values in Arctic and Subarctic marine waters and sediments. Microb. Ecol. 10: $151-164$

Jannasch, H. W., Wirsen, C. O. (1973). Deep-sea microorganisms: in situ response to nutrient enrichment. Science 180: $641-643$

Jannasch, H. W., Wirsen, C. O., Taylor, C. D. (1976). Undecompressed microbial populations from the deep sea. Appl. environ. Microbiol. 32: 360-367

Poremba, K. (1994). Simulated degradation of phytodetritus in deep-sea sediments of the NE Atlantic $\left(47^{\circ} \mathrm{N}, 19^{\circ} \mathrm{W}\right)$. Mar. Ecol. Prog. Ser. 105: 291-299

Porter, K. G., Feig, Y S. (1980). The use of DAPI for identifying and counting aquatic microflora. Limnol. Oceanogr. 29: $943-948$

Rheinheimer, G., Gocke, K., Hoppe, H. G. (1989). Vertical distribution of microbiological and hydrographic-chemical parameters in different areas of the Baltic Sea. Mar. Ecol Prog. Ser. 52: 55-70

Schwarz, J. R., Yayanos, A. A., Colwell, R. R. (1976). Metabolic activities ot the intestinal microflora of a deep-sea invertebrate. Appl environ. Microbiol. 31: 46-48

Tison, D. L., Pope, D. H. (1980). Effects of temperature on mineralization by heterotrophic bacteria. Appl. environ. Microbiol. 39: $584-587$

Turley, C. M. (1993). The effect of pressure on leucine and thymidine incorporation by free-living bacteria and by bacteria attached to sinking oceanic particles. Deep Sea Res. 40: 2193-2206

Wada, E., Koike, I., Hattori, A. (1975). Nitrate metabolism in abyssal waters. Mar. Biol. 29: 119-124

Yayanos, A. A., Dietz, A. S., Van Boxtel, R. R. (1979). Isolation of a deep-sea barophilic bacterium and some of its growth characteristics. Science 205: 808-810

Yayanos, A. A., Dietz, A. S. (1982). Thermal inactivation of deep-sea barophilic bacterium isolate CNPT-3. Appl. environ. Microbiol. 43: 1481-1489

Yayanos, A. A., Dietz, A. S., Van Boxtel, R. R. (1982). Dependence of reproduction rate on pressure as a hallmark of deep-sea bacteria. Appl. environ. Microbiol. 44: $1356-1361$

ZoBell, C. E., Johnson, F. H. (1949). The influence of hydrostatic pressure on the growth and viability of terrestrial and marine bacteria. J. Bacteriol. 57: 179-189

Manuscript first received: February 7, 1994

Revised version accepted: June 1, 1994 